\title{
Screening of poultry samples for Salmonella Typhimurium by PCR assay
}

\author{
V K Anumolu* and V R Lakkineni \\ Department of Veterinary Public Health \\ College of Veterinary Science, Sri Venkateswara Veterinary University, \\ Rajendrangar, Hyderabad - 500030 (AP) India \\ * Corresponding author email: anumoluvk2k@gmail.com \\ Received: 14-08-2011, Accepted: 20-09-2011, Published Online: 26-12-2011 \\ doi: $10.5455 /$ vetworld.2012.169-172
}

\begin{abstract}
Poultry samples viz., cloacal swabs, egg swabs, poultry faeces and feed were screened for Salmonella Typhimurium. A set of primers derived from fli C gene were employed to standardize PCR for detection of Salmonella Typhimurium from poultry samples, which gave specific amplification of a $620 \mathrm{bp}$ fragment. Boiling and snap chilling method used for template preparation. Screening of 112 samples revealed that 12 samples positive for Salmonella Typhimurium by PCR assay.
\end{abstract}

Keywords: Poultry samples, fli C gene, PCR, Salmonella Typhimurium

\section{To cite this article :}

Anumolu VK and Lakkineni VR (2012) Screening of poultry samples for Salmonella Typhimurium by PCR assay, Vet. World. 5(3):169-172, doi: 10.5455/vetworld.2012.169-172.

\section{Introduction}

Food safety hazards caused by food-borne pathogens such as Salmonella Typhimurium remain a major problem for the food industry, particularly poultry processors (USDA-2003). It is the major causes of food-borne disease throughout the world (Wang et al., 2008). Salmonella infected chickens represent a source of pathogens for humans, causing severe illness and even death. Salmonella Typhimurium is also the most frequently isolated serovar from global food-borne outbreaks. Poultry are one of the most important reservoirs of Salmonellae that can be transmitted to humans through the food-chain. The commonest serotypes causing disease in humans are $S$. enteritidis and S. Typhimurium (Aktas et al., 2007). Kotova et. al. (1988) observed that humans develop the salmonella carrier state after acute salmonellosis and it is due to result of occupational exposure to poultry $(6.1 \%-8.8 \%)$. There has long been an association between the contamination of eggs and egg products with salmonella and human infection (Humphrey,
2000). Poultry products can be major vehicles of food borne salmonellosis because the raw products are initially contaminated with salmonella cells (Bryan and Doyle 1995).

Salmonella enterica is mainly transmitted to humans following consumption of contaminated eggs and poultry products. Hence, a rapid detection and identification method of this serovar is necessary in the food industry (Lim et.al. 2003). The rapid, cost effective and automated diagnosis of food borne pathogens throughout the food chain continues to be a major concern for the industry and public health. The test supplies the growing demand for validated diagnostic PCR methods for screening of samples in meat production chain to assure safe food Lofstrom et. al. (2010).

\section{Materials and Methods}

Sample collection: 20 each cloacal swabs and egg swabs, 12 poultry faecal samples and 10 feed samples from poultry farm were aseptically collected from All India Coordinated Research (AICRP) on poultry for eggs, Hyderabad. Fifty 
chicken samples $(50 \mathrm{~g})$ were collected aseptically from local shops of Rajendranagar.

Enrichment of samples: Cloacal and egg swabs, faecal samples and feed samples were inoculated in buffered peptone water in test tubes $(50 \mathrm{ml})$ and incubated at $37^{\circ} \mathrm{C}, 16 \mathrm{~h}$. About $10 \mathrm{~g}$ of each chicken samples were inoculated into $90 \mathrm{ml}$ buffered peptone water (BPW) in individual sterile polythene bags homogenized thoroughly in a stomacher for 3 to $5 \mathrm{~min}$ and incubated at $37^{\circ} \mathrm{C}$ for $16 \mathrm{~h}$. Selective enrichment was done in Tetra thionate (TT) broth for which $1 \mathrm{ml}$ of pre-enrichment inoculum was transferred to TT $(10 \mathrm{ml})$ and were incubated at $42^{\circ} \mathrm{C}$ for $18 \mathrm{~h}$.

Bacterial strains: The bacterial strains Salmonella Typhimurium and Salmonella Enteritidis were obtained from Department of Veterinary Microbiology, College of Veterinary Science, Rajendranagar

DNA isolation: The genomic DNA isolation was carried out by phenol: chloroform: iso amyl alcohol method from the bacterial strain Salmonella Typhimurium to standardize PCR assay for detection of Salmonella Typhimurium. DNA templates were prepared from samples by boiling and snap chilling method. In this method, about $1000 \mu \mathrm{l}$ of the $24 \mathrm{~h}$ inoculums from the selective enrichment was centrifuged at $6000 \mathrm{rpm}$ for $5 \mathrm{~min}$ and resuspended in $50 \mu \mathrm{l}$ of molecular grade water. The suspension was then kept in a boiling water bath for $10 \mathrm{~min}$ and immediately transferred onto ice, later it was centrifuged at $13000 \mathrm{rpm}$ for $5 \mathrm{~min}$. for PCR technique, five $\mu \mathrm{l}$ of supernatant was used as template.

Standardization of PCR: The primers derived from fli C gene for detection of Salmonella Typhimurium were custom synthesized by integrated DNA technologies. The nucleotide sequence of the primers (Olivera et.al. 2002) used in this study was Fli 15 (22): 5'- CGG TGT TGC CCA GGT TGG TAA T-3' and Typ 04 (16): 5'- ACT GGT AAA GAT GGC T-3'. The PCR protocol was initially standardized by optimizing the concentration of the components of the reaction mixture in the PCR assay and by varying annealing temperatures and cycling conditions. The reaction mixture consisted of $5 \mathrm{ul}$ of the template, $2.5 \mu \mathrm{l}$ of $10 \mathrm{x}$ assay buffer for Taq polymerase containing $1.5 \mathrm{mM} \mathrm{MgCl}_{2}, 1 \mu \mathrm{l}$ of 25 $\mu \mathrm{M}$ each dNTP mix, $1 \mu 1$ each of forward and reverse primer ( 4 pmol) and $0.9 \mathrm{U} / \mu 1$ of Taq DNA polymerase made up to $25 \mu 1$ using molecular grade water. Routinely, master mix was prepared and $20 \mu 1$ each was distributed to the PCR tubes, to which $5 \mu \mathrm{l}$ of the template was added. Amplification was carried out with initial denaturation at $94{ }^{\circ} \mathrm{C}$ for $5 \mathrm{~min}$, followed by 35 cycles each of denaturation at $94^{\circ} \mathrm{C}$ for $1 \mathrm{~min}$, annealing at $45.1^{\circ} \mathrm{C}$ for $30 \mathrm{sec}$ and extension at $72^{\circ} \mathrm{C}$ for $38 \mathrm{sec}$ with a final extension period of $72^{\circ} \mathrm{C}$ at $7 \mathrm{~min}$. The amplification products were analyzed by agarose gel electrophoresis using $1.5 \%$ agarose gel containing $0.5 \mu \mathrm{g} / \mathrm{ml}$ ethidium bromide at constant voltage $5 \mathrm{~V} / \mathrm{cm}$ in $1 \mathrm{x}$ TAE.

\section{Results and Discussion}

In India the Salmonella has been isolated from variety of livestock foods including milk and milk products, eggs, fish, crustaceans, meat and meat products and also from various environmental samples collected from slaughter houses and fish processing plants (Nagappa et al 2007; Sharma et.al.,1995). There is wide difference in the isolation of Salmonella spp. by various scientists from various foods ranging from 0 (Ramasastry et.al. 1999) to $100 \%$ (Sharma et.al. 1989; Kamat et.al. 1991). These differences might be due to geographic, seasonal variations and also due to procedures adopted for isolation.

Therefore, there is a significant need for more rapid and/or sensitive methods for the identification of Salmonella. Several techniques have been developed to address this need, including DNA hybridization (Chevrier et.al. 1995), fluorescent antibodies and enzyme-linked immunosorbent assay (Fadeel et.al. 2004). However, sensitivity and specificity problems have limited the application of such methods, and there is still a need for a rapid, sensitive, specific and userfriendly method. One possible approach involves polymerase chain reaction based assay, which has become a powerful and increasingly popular tool 
in other areas of microbial detection and identification. As PCR relies on the detection of specific gene fragments, it can be applied in mixed microbial cultures, avoiding problems which may arise using other biochemical and morphological tests (Catarame et.al. 2005).

Several workers have used PCR with varied success for detection of Salmonella from foods using specific gene sequences for targeting (Bennett et.al. 1998; Chao et.al. 1998; Tsen and Chen, 2001). Of these, inv A gene and fli $\mathrm{C}$ gene have been the most frequently targeted genes for primer selection in PCR based Salmonella spp. detection (Chen and Griffiths, 2001) and at the serovar level, Salmonella Typhimurium was very specific because it could amplify $620 \mathrm{bp}$ fragments of fli $C$ gene in all standard $S$. typhimurium strains (Lin et al., 2007).

Screening of 112 samples revealed a wide variation in detection of Salmonella Typhimurium in poultry samples. Out of 50 chicken samples, 3 samples were positive for Salmonella Typhimurium. Out of 20 swabs from eggs, 4 swabs were positive. These observations were in accordance with the findings of Moussa et.al. (2010). One sample was found positive out of 10 feed samples analyzed. Out of 12 faecal samples and 20 cloacal swabs, one and 3 samples were positive. These findings are more or less similar to the results of Gonclaves et.al. (1998).

\section{Acknowledgement}

Authors are thankful to the Sri Venkateswara Veterinary University for providing funds under state plan budget to carry out my research work in the scheme entitled "Standardization of diagnostic techniques on food-borne infections with particular reference to Salmonella".

\section{Conflict of interest} interest.

Authors declare that they have no conflict of

\section{References}

1. Aktas, Z., Martin, D., Kayacan, C.B., Diren, $S$ and Threlfall E.J. (2007). Molecular characterization of Salmonella Typhimurium and Salmonella Enteritidis by plasmid analysis and pulsed-field gel electrophoresis. Inter. J. Antimicrob. Agent, 30: 541-545.

2. Bennett, A.R., Greenwood, D,. Tennant, C., Banks J.G. and Betts, R.P. (1998). Rapid and definitive detection of Salmonella in foods by PCR. Lett. Appl. Microbiol., 26: 437-441

3. Bryan, F.L., Doyle, M.P. (1995). Health risks and consequences of Salmonella and Campylobacter jejuni in raw poultry. $J$. Food Protect. 58 326-344.

4. Catarame, T.M.G., O'Hanlon, K.A., McDowell, D.A., Blair,I.S., and Duffy.G. (2005). Comparison of a real-time polymerase chain reaction assay with a culture method for the detection of Salmonella in retail meat samples. J. Food Safety. 26: 1-15.

5. Chao,J.C., Dey, R.L. and Yang, C.S.D. (1998). Rapid detection of Salmonella spp. In chicken samples. Food Sci. Taiwan, 25: 222-223.

6. Chen, S., Yee, A., Griffiths, M.W. (2001). Detection of Salmonella and simultaneous detection of Salmonella and Shiga-like toxin producing Escherichia coli using the magnetic capture hybridization polymerase chain reaction. Lett Appl Microbiol., 32: 7 11.

7. Chevrier, D., Popoff, M.Y., Dion, M.P., Hermant, D. and Guesdon, J.L. (1995). Rapid detection of Salmonella subspecies I by PCR combined with non-radioactive hybridization using covalently immobilised oligonucleotide on a microplate. FEMS Immunol. Med. Microbiol. 10, 245-501.

8. Fadeel, M.A., Crump, J.A., Mahoney, F.J., Nakhla, I.A., Mansour, A.M., Reyad, B. EL Melegi, D., Sultan, Y., Mintz., E.D. and Bibb, W.F. (2004). Rapid diagnosis of typhoid fever by enzyme-linked immunosorbent assay detection of Salmonella serotype typhi antigens in urine. Am. J. Trop. M ed . Hyg. 70, 323-328.

9. Goncalves, P.M.R., Franco, R.M., Zamborlini, L.C., (1998). Enumeracao de enterococos e colifirmes fecais, pesquisa de Salmonella e indicacao presuntiva de Proteus, em cortes e miudos de frango 
congelado. Hig. Aliment. 12, 42-47.

10. Humphrey, T. (2000). Public Helath aspects of Salmonella infection. In: Wray, C. and Wray, A. (eds.) Salmonella in domestic animals. CABI Publishing, U.K. pp. 245-264.

11. Kamat, A.S., Alur, M.D., Nerkar, D.P. and Nair, P.M. (1991) Hygienization of Indian chicken meat by ionizing radiation. $J$. Food Safety., 12: 59-71.

12. Kotova, A.L., Kondratskaya, S.A. and Yasutis, I.M. (1988). Salmonella carrier state and biological characteristics of the infectious agent.J Hyg. Epidemiol. Microbiol. Immunol., 32: 71-78.

13. Lim, Y.H., K. Hirose, H. Izumiya, E. Arakawa, H. Takahashi, and H. Watanabe. (2003). Multiplex polymerase chain reaction assay for selective detection of Salmonella enterica serovar Typhimurium. Jpn. J. Infect. Dis. 56:151-155.

14. Lin, C.L., Chiu, C.H., Chu, C., Huang, Y.C., Lin, T.Y. and Ou, J.T. (2007). A multiplex chain reaction method for rapid identification of Citrobacter freundii and Salmonella species, including Salmonella Typhi. J. Microbiol. Immunol. Infect. 40: 222-226.

15. Lofstrom, C., Hansen, F. and Hoorfar J. (2010). Validation $20 \mathrm{~h}$ real time PCR method for screening of Salmonella in poultry faecal samples. A. Vet. Microbiol.18.

16. Moussa, I. M., Gassem, M. A., Al-Doss, A. A., Mahmoud, W. A., Sadik and Abdel Mawgood, A. L. (2010). Using molecular techniques for rapid detection of Salmonella serovars in frozen chicken and chicken products collected from Riyadh, Saudi Arabia. African Journal of Biotechnology. 9(5): 612-619.

17. Nagappa, K., Shantanu T, Brajmadhuri, M.K., Saxena and S P Singh (2007). Isolation of Salmonella Typhimurium from poultry eggs and meat of Tarai region of Uttaranchal. Indian Journal of Biotechnology 6:407-409.

18. Ramasastry, P., Rao, R.M., and Mrunalini, N. (1999). Bacterial profiles of frozen meat. Indian Vet.J. 76: 409-411.

19. Sharma, V.D., Singh, Taku, A. and Dixit, V.P. (1989). Salmonella in goat, sheep and buffalo meat: occurrence and enterotoxigenicity. Indian J. Comp. Microbiol. Immunol. Infect. Dis., 10:180 - 185.

20. Sharma, V.D., Dixit, V.P. and Joshi, R.K. (1995). Occurrence of Salmonella serovars in foods of animal origin with special reference to antilbiogram and enterotoxigenicity. J. Food Sci. Technol., 32: 221-223.

21. Tsen, H.Y. and Chen, T.K. (2001). Development of DNA probes and PCR primers for the specific detection of food pathogens. Food Sci. Agricul. Chem., 3:1-7.

22. U.S. Food and Drug Administration, Center for Food Safety and Applied nutrition. (2003). Bad bug book - Salmonella.

23. Wang L, Shi L, Alam MJ, Geng Y, Li L (2008). Specific and rapid detection of foodborne Salmonella by loop-mediated isothermal amplification method. Food Res. Int. 41: 69-74. 